Tropical Journal of Pharmaceutical Research February 2020; 19 (2): 313-321

ISSN: $1596-5996$ (print); 1596-9827 (electronic)

(c) Pharmacotherapy Group, Faculty of Pharmacy, University of Benin, Benin City, 300001 Nigeria.

\title{
Phytochemical, antimicrobial and cytotoxicity screening of ethanol extract of Acacia ehrenbergiana Hayne grown in Jazan Region of Saudi Arabia
}

\author{
Hafiz A Makeen ${ }^{1}$, Hassan A Alhazmi ${ }^{2,3 \star}$, Asaad Khalid ${ }^{2,4}$, Mohammed Al Bratty ${ }^{3}$, \\ Sohier M Syame ${ }^{5,6}$, Ashraf N Abdalla ${ }^{4,7}$, Husham E Homeida ${ }^{5}$, Shahnaz \\ Sultana $^{8}$, Waquar Ahsan ${ }^{3}$ \\ ${ }^{1}$ Department of Clinical Pharmacy, College of Pharmacy, ${ }^{2}$ Substance Abuse Research Centre, ${ }^{3}$ Department of Pharmaceutical \\ Chemistry, College of Pharmacy, ${ }^{4}$ Medicinal and Aromatic Plants Research Institute, National Center for Research, PO Box \\ 2424, Khartoum-11111, Sudan, ${ }^{5}$ Faculty of Dentistry, Jazan University, PO Box 114, 45142, ${ }^{6}$ Department of Microbiology and \\ Immunology, National Research Centre, 33 Bohouth St. Dokki, Affiliation ID 60014618, 12311, Giza, Egypt, ${ }^{7}$ Department of \\ Pharmacology and Toxicology, Faculty of Pharmacy, Umm Al-Qura University, Makkah 21955, ${ }^{8}$ Department of \\ Pharmacognosy, College of Pharmacy, Jazan University, PO Box 114, 45142, Jazan, Saudi Arabia
}

*For correspondence: Email: hasalhazmi@gmail.com; Tel: +966-541433344

Sent for review: 16 September 2019

Revised accepted: 23 January 2020

\begin{abstract}
Purpose: To explore the phytoconstituents of Acacia ehrenbergiana Hayne as well as its biological effects.

Methods: Determination of phytoconstituents of ethanol extract of the plant was performed by gas chromatography-mass spectrometry (GC-MS) technique. Antibacterial screening was conducted against the isolates of Gram-positive and Gram-negative microbes while the anti-carcinogenic properties of the ethanol extract on cancerous cells were investigated by 3-(4,5-dimethylthiazol-2-yl)-2,5-diphenyl tetrazolium bromide (MTT) cytotoxicity assay against breast MCF7, ovary cancer A2780 and colon cancer HT29 cells, respectively, in addition to normal MRC5 fibroblast cells.

Results: GC-MS analysis identified 15 different phytochemicals in the ethanol extract. The extract exerted significant antimicrobial activity with the minimum inhibitory concentration (MIC) and minimum bactericidal concentration (MBC) in the range $1.56-6.25$ and $3.12-12.5 \mathrm{mg} / \mathrm{L}$, respectively, against all test bacterial strains. Cytotoxic activity, obtained by MTT assay, was $28.81 \pm 0.99,12.50 \pm 2.50,23.90 \pm$ 0.74 and $50.58 \pm 3.24 \mu \mathrm{g} / \mathrm{mL}$, against the three cancer cell lines and normal fibroblast, respectively. MTT cytotoxicity results was further confirmed by clonogenic survival assay on MCF7 cells.

Conclusion: This study highlights the potential interesting ethnopharmacological applications of Acacia ehrenbergiana Hayne to treat drug-resistant pathogens as standardized extract.
\end{abstract}

Keywords: Acacia ehrenbergiana, Phytochemistry, Antimicrobial, Cytotoxicity

This is an Open Access article that uses a fund-ing model which does not charge readers or their institutions for access and distributed under the terms of the Creative Commons Attribution License (http://creativecommons.org/licenses/by/4.0) and the Budapest Open Access Initiative (http://www.budapestopenaccessinitiative.org/read), which permit unrestricted use, distribution, and reproduction in any medium, provided the original work is properly credited.

Tropical Journal of Pharmaceutical Research is indexed by Science Citation Index (SciSearch), Scopus, International Pharmaceutical Abstract, Chemical Abstracts, Embase, Index Copernicus, EBSCO, African Index Medicus, JournalSeek, Journal Citation Reports/Science Edition, Directory of Open Access Journals (DOAJ), African Journal Online, Bioline International, Open-J-Gate and Pharmacy Abstracts

\section{INTRODUCTION}

Acacia ehrenbergiana Hayne (Fabaceae) is commonly found in the deserts of East Africa, northern Sahel, Arabian Peninsula, Southern and Central Sahara and is locally known as Salam. Higher salinity, $\mathrm{pH}$ and temperature tolerance makes this plant appropriate for the 
environmental conditions of Saudi Arabia [1,2]. Globular golden yellow fluffy flowers blossom in March and are about $1.5 \mathrm{~cm}$ wide which are visited by bees to make Acacia honey with high phenolic antioxidants [2,3]. Different acacia species have been used in folklore medicine and have high therapeutic values. Previously, ethanol extract of matured leaves showed significant anti-inflammatory activity [4], whereas, the polar and non-polar extracts of different parts of the tree (seeds, fruits, stem bark, leaves) showed effective antibacterial activity with no activity against most of the fungal species [5,6]. A $3 \%$ Stem bark ointment of the tree possessed complete wound healing and antibacterial activity as compared to tetracycline after 11 days of treatment in rats [7]. Salam from north and east Africa showed presence of Gallic acid, rutin, myricetin, methyl gallate, rutinoside, quercetin, and catechin [8]. Another species isolated from Aswan, Egypt showed presence of new acylated flavonol diglycoside, rutinoside (1), gallic acid (2), methyl gallate (3), quercetin-glucopyranoside (4), myricetin- $D$-glucopyranoside (5), rutin (6), myricetin- $D$-glucoside (7), quercetin- $D$-glucoside (8), myricetin (9), quercetin (10), catechin (11) in the aerial parts. Compounds 1, 2, 3, 5 and 10 illustrated good antibacterial and antifungal activity [8-11]. There is a need to develop alternative antimicrobial drugs for the treatment of infectious diseases from other non-synthetic sources, such as plants owing to the multiple drug resistance and adverse effects of currently used antibiotics [9].

Flavanoids, alkaloids, glycosides, tannins and saponins were also reported to be present in the plant collected from Saudi Arabia [6]. Till date, no data is available on the phytochemical constituents of Acacia ehrenbergiana Hayne locally grown in southern Saudi Arabia. Since, the constituents of the plant differ significantly from one region to another; this study was intended to explore the phytoconstituents using GC-MS and to test its antimicrobial and anticarcinogenic properties on breast, ovary and colon cancer cells, by MTT cytotoxicity assay.

\section{EXPERIMENTAL}

\section{Plant material}

Yellow flowers of $A$. ehrenbergiana Hayne were collected from Jazan in the month of March 2018 and were identified by Yahiya Masruhi, Department of Botany, Faculty of Science, Jazan University, Saudi Arabia. A voucher specimen no. JU/COP/18-1 was deposited in the departmental herbarium.

\section{Preparation of extracts}

Flowers were dried at room temperature and were used to prepare the extracts. Dried flowers $(100 \mathrm{~g})$ were milled and homogenized at 5000 rpm with $300 \mathrm{~mL}$ ethanol thrice for $24 \mathrm{~h}$. The combined extracts were mixed, filtered through Whattman paper $(0.45 \mu \mathrm{m})$, and dried under reduced pressure to obtain a dark colored mass. The residue thus obtained was kept at $4{ }^{\circ} \mathrm{C}$ in the dark until GC-MS analysis was performed.

\section{GC-MS analysis of the extract}

The flower extract suitably diluted in methanol $(1: 10 \mathrm{v} / \mathrm{v})$ was analyzed using Thermo Scientific GC-MS instrument equipped with AS 3000 auto sampler; trace ultra GC and ISQ detector. Thermo Scientific TR 5MS with dimensions of 30 $\mathrm{m} \times 0.25 \mathrm{~mm}$ (internal diameter) $\times 0.25 \mu \mathrm{m}$ (film thickness) was used for the separation of components. Helium, at a flow rate of $1.2 \mathrm{~mL} / \mathrm{min}$ (constant flow mode), was used as carrier gas. A volume of $2 \mu \mathrm{L}$ of sample extract was injected to the system in split less mode using auto sampler. The injection port was set at $320^{\circ} \mathrm{C}$ and the oven temperature was initially set at $70{ }^{\circ} \mathrm{C}$ for $5 \mathrm{~min}$, which was subsequently ramped to 205,280 , 290 and finally to $300{ }^{\circ} \mathrm{C}$ at a rate of $5{ }^{\circ} \mathrm{C} / \mathrm{min}$ and held for $5 \mathrm{~min}$ at each temperature. The maximum oven temperature was set at $320^{\circ} \mathrm{C}$. The mass spectrometer was operated in an electron ionization (EI) mode within the mass range of 60 - 900 amu with 0.6 scan times (min). The MS transfer line temperature and ion source temperature were kept at 320 and $350{ }^{\circ} \mathrm{C}$ respectively with electron multiplier voltage of 1 $\mathrm{Kv}$.

\section{Identification of constituents}

The mass spectra were interpreted using $X$ caliber software and the fragmentation patterns obtained for different components were matched with the structures stored in the database using MAINLIB, NIST and REPLIB built-in libraries. The constituent percentages were measured on the basis of peak area and the identification of components was based on comparison with compounds available in computer library (NIST and Willey) associated with the GC-MS instrument.

\section{Antimicrobial assays \\ Test microorganisms}

The extract was tested against three species of Gram positive bacteria, Staphylococcus aureus (ATCC 254996), Enterococus fecalis (ATCC 
254602) and Streptococcus pneumoniae (ATCC 254657) as well as four species of Gram negative organisms, Escherichia coli (ATCC 254607), Proteus mirabilis (ATCC 257440), Pseudomonas aeruginosa (ATCC 254992), Klebsiella pneumoniae (ATCC 254656) and one standard fungus, Candida albicans (ATCC 254625). The tested organisms were obtained from the Department of Microbiology, King Fahad Hospital, Jazan, Saudi Arabia.

\section{Preparation of the test organisms}

A loopful of isolated bacterial colonies was inoculated into $4 \mathrm{~mL}$ peptone water and allowed to incubate for $4 \mathrm{~h}$ at $37^{\circ} \mathrm{C}$. The turbidity of actively growing bacterial suspension was adjusted and matched with the standard turbidity of $0.5 \mathrm{Mc}$ Farland units [12]. The fungal cultures were retained on Sabouraud dextrose agar medium and incubated for 4 days at $25^{\circ} \mathrm{C}$. The resultant fungal suspension was then harvested and washed with $100 \mathrm{~mL}$ sterile normal saline solution and stored in refrigerator at $4{ }^{\circ} \mathrm{C}$ until used further.

\section{In vitro antimicrobial screening of extract}

To test the antibacterial activity of the plant extracts, cup plate agar diffusion method were adopted with some minor modifications [13]. In this method, $1 \mathrm{~mL}$ of the standardized bacterial stock suspension containing $10^{5}-10^{6}$ C.F.U/ mL was thoroughly mixed with $100 \mathrm{~mL}$ of Muller Hinton agar medium, kept at $45^{\circ} \mathrm{C}$. Aliquots of $20 \mathrm{~mL}$ of the resulting Muller Hinton agar media were distributed into sterile Petri-dishes and kept aside to set. Four cups of approximately $20 \mathrm{~mm}$ diameter were made in each of these plates using sterile cork borer number 4. Agar discs were removed and the holes were filled with 0.1 $\mathrm{mL}$ of plant extracts and allowed to get diffused at room temperature for minimum $2 \mathrm{~h}$. All these plates were kept in incubator for $18 \mathrm{~h}$ at $37^{\circ} \mathrm{C}$ temperature. All the experiments were carried out in duplicate and the diameters of resulting zone of inhibition were measured and the mean values were reported. Similar procedure was adopted for testing the extract for antifungal activity. Instead of Muller Hinton agar, Sabouraud-dextrose agar medium was utilized and the incubation was performed for 2 days at $25^{\circ} \mathrm{C}$ in case of Candida albicans fungi.

\section{Minimum inhibitory concentration determination}

(MIC)

Minimum inhibitory concentration (MIC) was determined for the crude extract of Acacia ehrenbergiana Hayne against the microorganisms using broth microdilution method. Test bacterial cultures $(100 \mu \mathrm{L}$ of bacterial culture containing $10^{5} \mathrm{CFU} / \mathrm{mL}$ ) were inoculated into tubes containing different concentrations of extract of $25,12.5,6.25,3.12$, $1.56,0.78$ and $0.39 \mathrm{mg} / \mathrm{L}$ and incubated for $24 \mathrm{~h}$ at $37{ }^{\circ} \mathrm{C}$. The values were determined by detecting the inhibition of visible growth in the culture tubes. Similarly, Minimum Bactericidal Concentration (MBC) was measured by subculturing the broth onto freshly prepared solid media and further incubated at $37^{\circ} \mathrm{C}$ for $24 \mathrm{~h}$. The least concentration of MIC tubes which did not reveal any sign of growth of bacterial colonies was regarded as MBC [14].

\section{Morphological analysis}

A thin film of treated bacterial cell solutions of $S$. aureus, $E$. coli and $P$. aeruginosa were inoculated with $50 \mu \mathrm{L}$ of the $A$. ehrenbergiana solution (1 mg/L) and were smeared on a silver stub for SEM analysis $[15,16]$. All the samples were coated with gold using cathodic spraying (Polaron gold) technique and were dried under mercury lamp for $5 \mathrm{~min}$. The morphological changes in the microorganisms were assessed by scanning electron microscope after 18 and 24 $h$ of the inoculation.

\section{Cytotoxicity assay}

Three cancer cell lines, A2780 (human ovary adenocarcinoma), MCF7 (human breast adenocarcinoma) and HT29 (human colon adenocarcinoma) were used in this study, along with MRC5 (normal human fetal lung fibroblast) cells. All cells were obtained from the ATCC. The three cancer cell lines were sub-cultured in RPMI-1640 media (in $10 \%$ Fetal Bovine Serum (FBS); whereas, MRC5 was cultured in Eagles minimum essential medium (EMEM, in $10 \%$ FBS); kept at $37^{\circ} \mathrm{C}, 5 \% \mathrm{CO}_{2}$ and $100 \%$ relative humidity).

The cytotoxicity of the extracts were evaluated using MTT assay following the procedure described previously [17]. The three cancer cell lines and one normal fibroblast were separately cultured in 96-well $\left(3 \times 10^{3} /\right.$ well $)$ plate and incubated at $37{ }^{\circ} \mathrm{C}$ overnight. Different plant extract concentrations of $0,6.25,12.5,25,50$, $100 \mu \mathrm{g} / \mathrm{mL}$ were prepared in DMSO $(0.1 \% ; \mathrm{n}=$ 3 ), added to the plates and incubated for $72 \mathrm{~h}$, followed by addition of MTT to each well. Plates were incubated further for $3 \mathrm{~h}$, supernatant was aspirated followed by addition of DMSO to each well. Absorbance was measured on a multi-plate reader. Optical density of the purple formazan $A_{550}$ was considered to be proportional to the 
number of viable cells. Compound concentration causing $50 \%$ inhibition $\left(\mathrm{IC}_{50}\right)$ compared to control cell growth (100\%) was determined.

\section{Clonogenic assay}

Clonogenic assay is used to measure survival of tumor cells and their subsequent proliferative ability upon exposure to drugs $[18,19]$. Exponentially growing MCF7 cells in DMEM (previously supplemented with $10 \%$ FBS $+1 \%$ Penicillin/Streptomycin) media were seeded in duplicates at a density of 200 cells per well in a six-well plate and allowed to get attached for overnight. The cells were then exposed to increasing concentrations of ethanol extract $(0$, $12.5,25$ and $50 \mu \mathrm{g} / \mathrm{mL}$ ) of plant and incubated for $72 \mathrm{~h}$. Wells containing media with extract were replaced with fresh media without extract. Cells were left to grow at $37{ }^{\circ} \mathrm{C}, 5 \% \mathrm{CO}_{2}$ and $100 \%$ humidity. Wells were checked every day and cells forming colonies were roughly counted. After incubation for 14 days, the plates were rinsed thoroughly using PBS and fixed with chilled methanol for $20 \mathrm{~min}$ at room temperature. The plates were then stained with 0.5 methylene blue solution prepared in $1: 1$ methanol $/ \mathrm{H}_{2} \mathrm{O}(\mathrm{v} / \mathrm{v})$ for $10 \mathrm{~min}$, rinsed well using distilled water and finally dried in air. Cell colonies were counted macroscopically and reported.

\section{Statistical analysis}

Data were statistically analyzed using SPSS (IBM Inc, USA) version 20 software and are reported as mean \pm standard error of mean (SEM). Differences between groups were accordingly assessed by inferential statistics. $P$ $<0.05$ was considered statistically significant.

\section{RESULTS}

\section{Phytochemical composition of plant extract}

The phytochemical compounds identified in $A$. ehrenbergiana Hayne ethanol extract of flowers are tabulated in Table 1. These components are arranged in order of GC elution on TR-5MS column. Total $57.67 \%$ of phytoconstituents were calculated from ISQD chromatograms and relative concentration of each compound in the extract was quantified according to the peak area integrated by the analysis program. The extract was characterized by a large number of higher alkanes $(10.11 \%)$, glycerides $(18.85 \%)$, caroteneoid pigments $(2.66 \%), \quad 9,15-$ diazatetracyclo-hexadeca-tetraen-11-yl) methyl acetate $(5.47 \%)$, propanoic acid ester $(1.01 \%)$, oxaspiro(4,5)deca-6,9-diene $\quad(4.25 \%)$, phytosterol (1.76\%), azulene derivative $(1.93 \%)$ and acetic acid derivatives (1.66 \%). Heptacosane (2.29 \%), 2-methyl- nonadecane (2.77 \%), 2-methyl-eicosane (1.16\%), 3-ethyl-5(2-ethylbutyl)-octadecane $(2.66 \%)$ and tetratetracontane $(1.51 \%)$, were different derivatives of higher alkanes found in the flowers.

Table 1: Phytochemical constitents of ethanol extract of the flowers of $A$. ehrenbergiana

\begin{tabular}{|c|c|c|c|c|c|}
\hline $\begin{array}{l}\text { S. } \\
\text { no }\end{array}$ & $\begin{array}{l}\text { Retention } \\
\text { time }\end{array}$ & Chemical constituent & MW & $\begin{array}{l}\text { Molecular } \\
\text { formula }\end{array}$ & $\begin{array}{c}\% \\
\text { Area }\end{array}$ \\
\hline 1 & 5.62 & Dasycarpidan-1-methanol, acetate (ester) & 326 & $\mathrm{C}_{20} \mathrm{H}_{24} \mathrm{O}_{5}$ & 5.47 \\
\hline 2 & 18.88 & $\begin{array}{l}\text { Propanoic acid, 2-methyl-, } \\
\text { trimethylpentyl ester }\end{array}$ & 216 & $\mathrm{C}_{12} \mathrm{H}_{24} \mathrm{O}_{3}$ & 1.01 \\
\hline 3 & 31.25 & $\begin{array}{l}\text { 7,9-Di-tert-butyl-1-oxaspiro(4,5)deca-6,9-diene-2,8- } \\
\text { dione }\end{array}$ & 276 & $\mathrm{C}_{17} \mathrm{H}_{24} \mathrm{O}_{3}$ & 4.25 \\
\hline 4 & 31.71 & Heptacosane & 380 & $\mathrm{C}_{27} \mathrm{H}_{56}$ & 2.29 \\
\hline 5 & 32.07 & 2-methyl- Nonadecane & 282 & $\mathrm{C}_{20} \mathrm{H}_{42}$ & 2.77 \\
\hline 6 & 37.0 & 2-methyl- Eicosane & 296 & $\mathrm{C}_{21} \mathrm{H}_{44}$ & 1.16 \\
\hline 7 & 40.48 & 1,8-Diazacyclotetradecane & 226 & $\mathrm{C}_{12} \mathrm{H}_{22} \mathrm{~N}_{2} \mathrm{O}_{2}$ & 2.38 \\
\hline 8 & 42.58 & 3-ethyl-5-(2-ethylbutyl)- Octadecane & 366 & $\mathrm{C}_{26} \mathrm{H}_{54}$ & 2.66 \\
\hline 9 & 43.35 & Tetratetracontane & 618 & $\mathrm{C}_{44} \mathrm{H}_{90}$ & 1.51 \\
\hline 10 & 53.09 & 1-Monolinoleoylglycerol & 498 & $\mathrm{C}_{27} \mathrm{H}_{54} \mathrm{O}_{4} \mathrm{Si}_{2}$ & 18.85 \\
\hline 11 & 56.41 & Lycopene & 536 & $\mathrm{C}_{40} \mathrm{H}_{56}$ & 0.78 \\
\hline 12 & 59.06 & 1,1',2,2'-tetrahydro-1,1'-dimethoxy-Carotene & 600 & $\mathrm{C}_{42} \mathrm{H}_{64} \mathrm{O}_{2}$ & 1.88 \\
\hline 13 & 60.76 & $\beta$-Sitosterol & 414 & $\mathrm{C}_{29} \mathrm{H}_{50} \mathrm{O}$ & 1.76 \\
\hline 14 & 66.59 & $\begin{array}{l}\text { 4a,5,7b,9,9a(1aH)-pentol,3-[(acetyloxy)methyl]- } \\
\text { 1b,4,5,7a,8,9-hexahydro-1,1,6,8-tetramethyl-5,9,9a- } \\
\text { triacetate,1H-cyclopropa[3,4]benz[1,2-e]azulene }\end{array}$ & 534 & $\mathrm{C}_{28} \mathrm{H}_{38} \mathrm{O}_{10}$ & 1.93 \\
\hline 15 & 67.83 & $\begin{array}{l}\text { 17-(4-chloro-5-methoxy-1,5-dimethylhexyl)- } \\
4,4,10,13,14-\text { pentamethyl- } \\
2,3,4,5,6,7,10,11,12,13,14,15,16,17 \text {-tetradecahydro- } \\
\text { 1-acetic acid }\end{array}$ & 534 & $\mathrm{C}_{33} \mathrm{H}_{55} \mathrm{ClO}_{3}$ & 1.66 \\
\hline
\end{tabular}


Two carotenoids (tetraterpenoid), lycopene ( 0.78 $\%$ and 1,1',2,2'-tetrahydro-1,1'-dimethoxycarotene $(1.88 \%)$ were also present which were responsible for the yellow color of the flower. Individually identified constituents from flowers collected from Jazan were 1monolinoleoylglycerol (18.85 \%), $\beta$-sitosterol $(1.76 \%), \quad 4 a, 5,7 b, 9,9 a(1 a H)$-pentol and 3[(acetyloxy)methyl]-1b,4,5,7a,8,9-hexahydro-

1,1,6,8-tetramethyl-,5,9,9a-triacetate, $1 \mathrm{H}$ -

cyclopropa[3,4]benz[1,2-e]azulene (1.93\%) derivative. The structures of some important components present in ethanol extract are given in Figure 1.

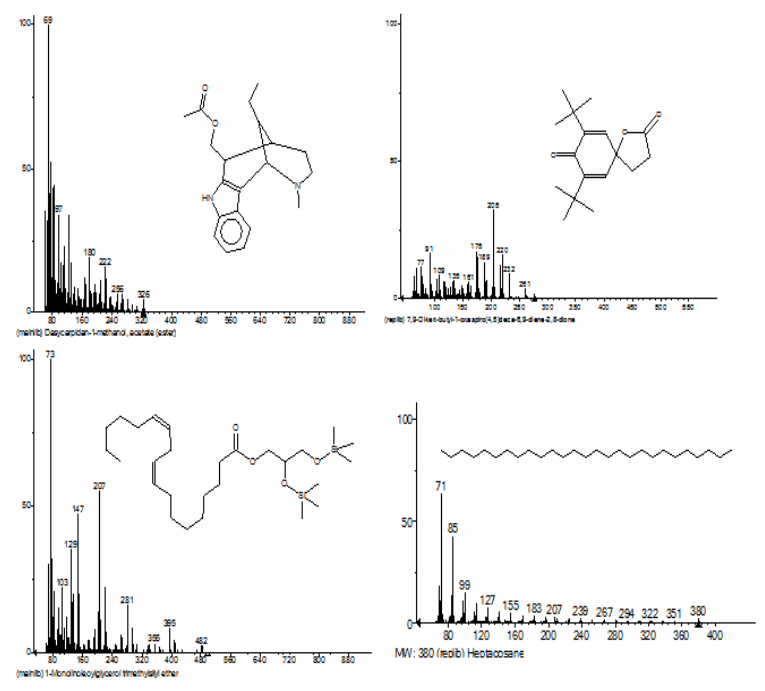

Figure 1: Structure and mass spectra of some major chemical components detected in $A$. ehrenbergiana

\section{Antibacterial activity}

The antibacterial efficacy of ethanol extract of $A$. ehrenbergiana against bacteria was examined by the disc-diffusion method and the results are shown in Table 2. Plant extract was found to be effective against the isolates of Gram-positive microorganisms, $S$. aureus and $E$. fecalis as well as Gram-negative organisms, $E$. coli, $P$. aeruginosa, $P$. mirabilis and $K$. pneumonia which were resistant to one or more commercially available antibiotics. The diameter of zone of inhibition was found to be in the range of $15-22$ $\mathrm{mm}$ against various bacterial strains tested, with maximum diameter against $S$. aureus $(22 \pm 0.3$ $\mathrm{mm}$ ) bacteria. Antibacterial activity measured by the disc-diffusion method has some limitations as it only indicates the bacterial growth inhibition without any evidence of the bacteriostatic or bactericidal action of the extract. Therefore, determination of MIC and MBC values of extract is used to establish the dose specificity and nature of the activity of the extract. Minimum inhibitory concentration (MIC) values of $A$. ehrenbergiana were estimated using broth macro-dilution method, whereas, MBC values were determined by sub-culturing all prepared concentrations $(\geq \mathrm{MIC})$ with no detectable growth. The MIC and MBC values of $A$. ehrenbergiana were calculated to be in the range of $1.56-6.25 \mathrm{mg} / \mathrm{L}$ and $3.12-12.5 \mathrm{mg} / \mathrm{L}$, respectively against all bacterial strains tested as shown in Table 2.

Table 2: Diameter of zone of inhibition, minimum inhibitory concentration (MIC) and minimum bactericidal concentration (MBC) of $A$. ehrenbergiana ethanol extract

\begin{tabular}{|c|c|c|c|}
\hline Microbial strain & $\begin{array}{l}\text { MBC } \\
(\mathrm{mg} / \mathrm{L})\end{array}$ & $\begin{array}{l}\text { MIC } \\
(\mathrm{mg} / \mathrm{L})\end{array}$ & $\begin{array}{c}\text { Zone of } \\
\text { inhibition } \\
\text { diameter } \\
(\mathrm{mm}, \\
\text { Mean } \pm \\
\text { SEM) }\end{array}$ \\
\hline DMSO & - & - & - \\
\hline Staphylococcus & 3.12 & 1.56 & $22 \pm 0.3$ \\
\hline $\begin{array}{l}\text { aureus } \\
\text { 254996) }\end{array}$ & & & \\
\hline $\begin{array}{l}\text { Enterococus fecalis } \\
\text { (ATCC 254602), }\end{array}$ & 12.5 & 6.25 & $18 \pm 0.2$ \\
\hline $\begin{array}{l}\text { Streptococcus } \\
\text { pneumonia } \\
254657 \text { ) (ATCC }\end{array}$ & $-{ }^{a}$ & - & - \\
\hline $\begin{array}{ll}\text { Escherichia } & \text { coli } \\
\text { (ATCC 254607) } & \\
\end{array}$ & 3.12 & 1.56 & $15 \pm 0.1$ \\
\hline $\begin{array}{l}\text { Klebsiella pneumoniae } \\
\text { (ATCC 254656) }\end{array}$ & - & - & - \\
\hline $\begin{array}{l}\text { Pseudomonas } \\
\text { aeruginosa } \\
254992 \text { ) }\end{array}$ & 6.25 & 3.12 & $18 \pm 0.2$ \\
\hline $\begin{array}{l}\text { Proteus mirabilis } \\
\text { (ATCC 257440), }\end{array}$ & 12.5 & 6.25 & $18 \pm 0.4$ \\
\hline $\begin{array}{l}\text { Candida albicans } \\
\text { (ATCC 254625). }\end{array}$ & - & - & - \\
\hline
\end{tabular}

The effects of $A$. ehrenbergiana on the membrane morphology of $E$. coli reference strain ATCC 254607, S. aureus reference strain ATCC 254996 and $P$. aeruginosa reference strain ATCC 254992 were demonstrated using Scanning Electron Microscopy (SEM). Untreated bacterial cells showed normal intact outer cell membrane and retained their morphology. Following incubation with $A$. ehrenbergiana at concentration $1 \mathrm{mg} / \mathrm{L}$, physical damage and irregularities and rupture were observed on the cell membrane of treated bacteria.

The treatment of bacteria with the extract of $A$. ehrenbergiana also resulted in partial deformation of the cell wall and formation of cavities in cells as well as shrinkage, aggregation and ultimately ruptures. SEM images of tested microbial strains after the treatment showed distorted shapes and lost of integrity of bacterial 
cells after 18 and $24 \mathrm{~h}$ of incubation as depicted in Figure 2.
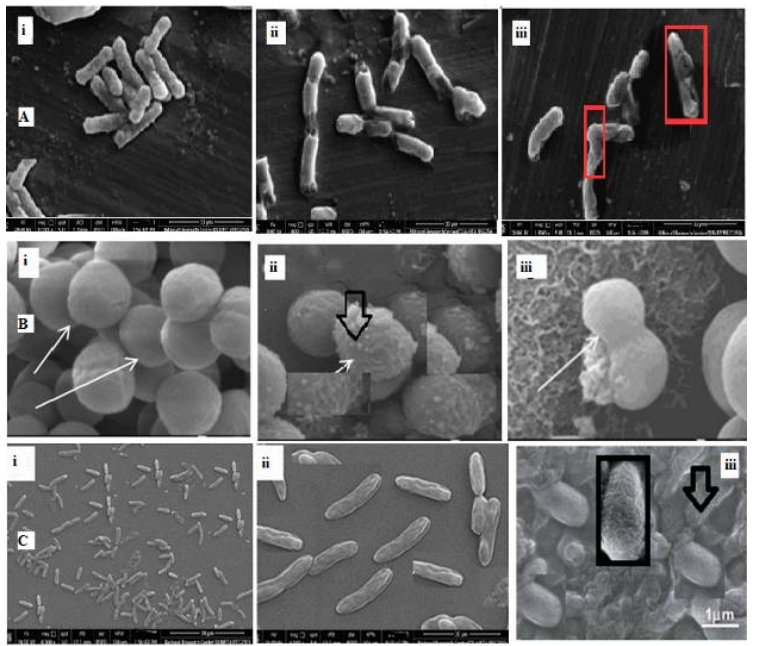

Figure 2: Morphology of A) E. coli, B) S. aureus and C) $P$. aeruginosa bacterial cells observed by Field Emission Scanning Electron Microscopy. (i) untreated cells (control), (ii) treated cells with $1 \mathrm{mg} / \mathrm{L}$ concentration of $A$. ehrenbergiana for $18 \mathrm{~h}$ and (iii) treated cells with $1 \mathrm{mg} / \mathrm{L}$ concentration of $A$. ehrenbergiana for $24 \mathrm{~h}$. The surface damage and adsorption of $A$. ehrenbergiana on the bacterial cell is marked

\section{Cytotoxicity and clonogenic assays}

The cytotoxic activity (MTT $72 \mathrm{~h}, \mathrm{IC}_{50} \pm \mathrm{SD}$ $\mu \mathrm{g} / \mathrm{mL}$ ) of the ethanol extract of $A$. ehrenbergiana Hayne against three cancer cell lines MCF7, A2780 and HT29 as well as against normal fibroblast cells, MRC5 was found to be $28.81 \pm$ $0.99,12.50 \pm 2.50,23.90 \pm 0.74$ and $50.58 \pm$ $3.24 \mu \mathrm{g} / \mathrm{mL}$, respectively (Table 3 ).

Table 3: Cytotoxic activity of the ethanol extract of $A$. ehrenbergiana against three cancer cell lines and one normal fibroblast (MTT $72 \mathrm{~h}, \mathrm{IC}_{50} \pm \mathrm{SD} \mu \mathrm{g} / \mathrm{mL}$ )

\begin{tabular}{lc}
\hline Cell line & IC $_{50} \pm \mathbf{S D}(\boldsymbol{\mu} \mathbf{g} / \mathbf{m L})$ \\
\hline MCF7 & $28.81 \pm 0.99$ \\
A2780 & $12.50 \pm 2.50$ \\
HT29 & $23.90 \pm 0.74$ \\
MRC5 & $50.58 \pm 3.24$ \\
\hline
\end{tabular}

Clonogenic survival assay was performed to test the clonogenic effect of ethanol extract on MCF7 cells. Cells were observed after $72 \mathrm{~h}$ of exposure to the ethanol extract, followed by 14 days incubation in fresh nutrient medium. The plant extract inhibited the growth of MCF7 colonies (Figure 3) in a concentration dependent manner. The result of the clonogenic survival assay further supported the MTT results reported in this study.

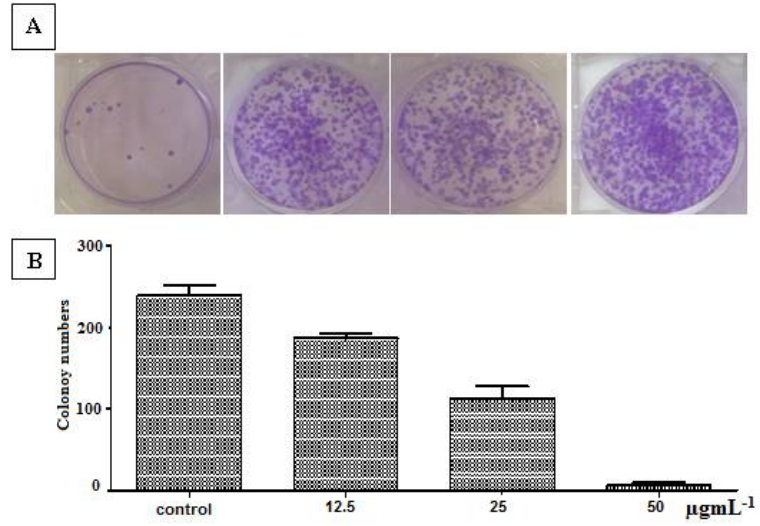

Figure 3: Clonogenic results. A: Colonies of MCF7 treated with ethanol extract (from left 0, 12.5, 25 and $50 \mu \mathrm{g} / \mathrm{mL}$ concentration; $\mathrm{n}=3$ ) in 6 well plates following 14 days of extract-free incubation. B: bar graph showing ethanol extract concentrations (X-axis) and colony numbers (Y-axis). Results are expressed as cell number $\pm S D$ of three independent experiments

\section{DISCUSSION}

Using GC-MS, $56.09 \%$ phytoconstituents from ethanol extract were identified. Components such as dasycarpidan-1-methanol acetate (ester), $\quad \beta$-sitosterol, 1-monolinoleoylglycerol, squalene, octacosanol, $\alpha$-amyrin and lupeol have been previously reported to have antibacterial, antifungal, anti-inflammatory, anti-pyretic, antidiabetic and anticancer activities [20-22].

Other important detected constituents including 7,9-di-tert-butyl-1-oxaspiro(4,5)deca-6,9-diene-

2,8-dione, heptacosane, 1,1',2,2'-tetrahydro-1,1'dimethoxy-carotene, lycopene and 2-methyleicosane are well known antioxidants. On the other hand, 2-methyl-eicosane, 3-ethyl-5-(2ethylbutyl)-octadecane, 1-heptacosanol, tetratetracontane, and 2-methyl-nonadecane are known antimicrobial agents [23,24]. Among the antioxidant components, ç-tocopherol, squalene, $\beta$-sitosterol, hentriacontane, heptacosane, 2methyl-eicosane, octacosane, heneicosane were the most abundant ones which are produced by mature flowers of the plant $[25,26]$.

Plants are one of the major sources of naturally occurring antibacterial compounds [27]. Development of newer antimicrobial agents is urgently needed owing to the harmful side effects and antibiotic resistance associated with the existing antimicrobial compounds. Therefore, medicinal plants have now been evaluated as newer antibiotics owing to their potent activity. The study was aimed to investigate the antimicrobial efficacy of locally grown $A$. ehrenbergiana Hayne (Salam) species extracts as a grazing herb against some medicinally significant pathogens. Three Gram positive 
standard bacterial strains ( $S$. pneumoniae, $S$. aureus and $E$. fecalis) and four Gram negative standard bacteria; strains ( $E$. coli, $K$. pneumoniae, $P$. mirabilis and $P$. aeruginosa) as well as one standard fungus (Candida albicans) were tested.

The results obtained are summarized in Table 2 and they show that ethanol extract of the plant exhibited significant antimicrobial activities against most of the pathogens including $S$. aureus, E. fecalis, E. coli, $P$. aerogenes and $P$. mirabilis as demonstrated by agar well diffusion method. However, the extract did not reveal any significant antifungal efficacy against the tested fungal strain $C$. albicans. These results were in concordance with the results obtained by ElDesoukey et al [6]. and Rahim et al [7], who reported that the methanol and aqueous extract of $A$. ehrenbergiana displayed a wide range of activity when tested against a number of bacterial strains with promising MIC values. The methanol extract of $A$. ehrenbergiana was explored for its antimicrobial activity, which displayed a wide spectrum of activity against a number of bacterial isolates with a weak inhibitory action on tested fungal strains. In contrast, Younis et al [28] reported that the aqueous, ethanol and ethyl acetate extracts of $A$. ehrenbergiana shoots showed moderate antimicrobial activity.

The presence of biologically active constituents such as saponins, alkaloids, flavonoids and tannins in leaves and flowers in varying concentrations might be responsible for the antibacterial efficacy of $A$. ehrenbergiana [28]. The antimicrobial action of tannins obtained from the plant has been demonstrated through coagulating the protoplasm of the microorganism [28]. Biological functions of flavonoids include removal of beta toxins, reduction of inflammation, protection against allergies, platelet aggregation, treatment of ulcer, scavenging free-radicals, killing microbes and treatment of tumors [6,29]. The MIC values as shown in Table 2 were observed to be lesser in the current study as compared to the previously reported [30] values.

The results obtained in the microscopic studies are in agreement with the previous report, demonstrating irreversible damage which greatly occur to bacterial membranes, leading to loss of the most essential cellular components such as nucleic acids and proteins after the treatment with the plant extract [31]. To evaluate the antibacterial action, it is necessary to investigate the changes in morphology, surface characteristics, membrane permeability and integrity of the bacterial cell before and after treatment with extract [31]. The morphological and physiological changes in E. coli, $S$. aureus and $P$. aeruginosa (Figure $2 \mathrm{~A}-\mathrm{I}$ ) were observed by scanning electron microscopy (SEM) technique before and after treatment with $A$. ehrenbergiana extract. Results showed obvious and direct destructive effects of the extract on tested organisms and distinct morphological changes as compared to untreated ones. Most of the treated bacterial cells appear broken, pitted and deformed after 18 and $24 \mathrm{~h}$ of the treatment. These investigations supported the results of integrity and cell permeability assay and ensured that the $A$. ehrenbergiana extract had major effects on the cytoplasmic membrane and cell wall of bacteria.

\section{CONCLUSION}

A total of 15 phytoconstituents have been identified from the ethanol extract of $A$. ehrenbergiana Hayne grown in the southern part of Saudi Arabia. The extract exhibits promising antimicrobial effects against several bacterial strains including $S$. aureus, E. fecalis, E. coli, $P$. mirabilis, $P$. aeruginosa and $K$. pneumoniae. This extract also has potential anti-carcinogenic activities against breast, ovary and colon cancer cell lines. Further preclinical and clinical studies are required to elucidate the exact mechanism of antimicrobial and cytotoxic activities of the plant.

\section{DECLARATIONS}

\section{Acknowledgement}

Authors are thankful to the Deanship of Scientific Research, Jazan University for providing financial assistance (Research Group no. RG-39) to carry out this research work.

\section{Conflict of interests}

The authors declare that no conflict of interest, financial or otherwise, is associated with this work.

\section{Contribution of authors}

This work was done by the author(s) named in this article and all liabilities pertaining to claims and contents will be borne by the authors. Hafiz A. Makeen and Hassan A. Alhazmi carried out the conceptualization and design of the study and experimental design. Asaad Khalid, Mohammed Al Bratty, Sohier M. Syame, Ashraf N. Abdalla, and Husham E. Homeida carried out the experimental work and data analysis. Shahnaz Sultana and Waquar Ahsan wrote and 
proofread the manuscript. All the authors read and approved the manuscript for publication.

\section{Open Access}

This is an Open Access article that uses a funding model which does not charge readers or their institutions for access and distributed under the terms of the Creative Commons Attribution License (http://creativecommons.org/licenses/by/ 4.0) and the Budapest Open Access Initiative (http://www.budapestopenaccessinitiative.org/rea d), which permit unrestricted use, distribution, and reproduction in any medium, provided the original work is properly credited.

\section{REFERENCES}

1. Alshaharani TS, Shetta ND. Phenotypic and biochemical characterization of root nodule bacteria naturally associated with woody tree legumes in Saudi Arabia. $J$ Environ Biol 2015; 36(2): 363-370.

2. Houérou L. Acacia ehrenbergiana Hayne, Tropical Forages: Grassland. FAO [updated 2013 March 23; cited 2019 April 11]. Available from: http://www.fao.org/ag/AGP/AGPC/doc/gbase/DATA/PFO 00354.html.

3. Al-Mamary M, Al-Meeri A, Al-Habori M. Antioxidant activities and total phenolics of different types of honey. Nutr Res 2002; 22(9): 1041-1047.

4. Mohammad II, Alsafi MY, Al-Mahdi MMA, Elsammani TO, Mudawi MME. Evaluation of anti-inflammatory activity of Acacia ehrenbergiana (Salam) leaves by in-vivo and invitro models. Indo Am J Pharm Sci 2017; 4(1): 26-32.

5. Younis M, Elmegeed GA, Nassar MI. Antimicrobial activities of Acacia ehrenbergiana extracts and its nitrogen fixation ability. Egypt $J$ Microbiol 2003; 38(2): 195-205.

6. El-Desoukey RMA. Phytochemical and antimicrobial activity of Acacia ehrenbergiana Hayne (Salam) as a grazing herb against some animal pathogens. Adv Anim Vet Sci 2018; 6(6): 246-251.

7. Rahim SAA, Almagboul AZ, Mohammed NEB. Antimicrobial activity of Croton zambesicus, Acacia ehrenbergiana and Fagonia cretica. Nat J Adv Res 2016; 2(3): 16-20.

8. Gaara AH, Nassar MI, Younis M, Elmegeed GA, Mabry TJ, Pare PW. Biologically active polyphenolic compounds from Acacia ehrenbergiana. Rev Latinoamer Quím 2008; 36: 2.

9. Anitha $T$, editors. Indian mulberry (Morinda citrifolia, Rubiaceae) [monograph on internet]. Munich: GRIN Publishing GmbH; 2009 [cited 2019 Apr 11]. Available from: http://www.grin.com/en/e-book/201756/indianmulberry-morinda-citrifolia-rubiaceae.

10. Abdalla MS, Babiker IA, Elkalifa KF. Chemical analysis of Acacia ehrenbergiana (salam) tree fruits (seed and pods) as dry season supplement for livestock in arid and semi-arid lands of Sudan. Anim Rev 2015; 2(3): 76-80.

11. Contu S, editors. Acacia ehrenbergiana. The IUCN red list of threatened species [monograph on internet]. International Union for Conservation of Nature; 2012 [cited 2019 Apr 11]. Available from: https://www.iucnredlist.org/species/19892054/19997854

12. Cheesbrough M. Medical laboratory manual for tropical countries. Low-priced ed. Cambridge: Butterworth and Co Ltd; UK, 2008.

13. Kavanagh F. Analytical Microbiology. New York: Academic Press; USA, 1972.

14. CLSI. Methods for dilution antimicrobial susceptibility tests for bacteria that grow aerobically, approved standard. 9th ed. CLSI document M07-A9. Pennsylvania: Clinical and Laboratory Standards Institute; Wayne, USA, 2012.

15. Walsh $C$, editors. Antibiotics: Actions, origins, resistance [monograph on internet]. American society for microbiology (ASM) Application; 2003 [cited 2019 Apr 15]. Available from: https://doi.org/10.1128/97815558 17886.

16. Breukink E, de Kruijf B. Lipid II as a target for antibiotics. Nat Rev Drug Discov 2006; 5: 321-323.

17. Bkhaitan MM, Mirza AZ, Abdalla AN, Shamshad H, UlHaq Z, Alarjah M, Piperno A. Reprofiling of full-length phosphonated carbocyclic 2'-oxa-3'-aza nucleosides towards antiproliferative agents: Synthesis, antiproliferative activity and molecular docking study. Chem Biol Drug Des 2017; 90: 679-689.

18. Brown JM, Wouters BG. Apoptosis, p53 and tumor cell sensitivity to anticancer agents. Cancer Res 1999; 59(7): 1391-1399.

19. Franken NA, Rodermond HM, Stap J, Haveman J, van Bree C. Clonogenic assay of cells in vitro. Nat Protoc 2006; 1(5): 2315-2319.

20. Al-Rubaye1 AF, Kaizal AF, Hameed IH. Phytochemical screening of methanolic leaves extract of Malva sylvestris. Int J Pharmacog Phytochem Res 2017; 9(4): 537-552

21. Raman BV, Samuel LA, Saradhi MP, Rao NB, Krishna NVA, Sudhakar M, Radhakrishnan TM. Antibacterial, antioxidant activity and GC-MS analysis of Eupatorium odoratum. Asian Pharm Clin Res 2012; 5: 2.

22. Aurangzeb M, Khan SU, Rahman TU, Sajid M, Seloni S. Isolation and biological activity of $\beta$-sitosterol and stigmasterol from the roots of Indigofera heterantha. Pharm Pharmacol Int J 2017; 5(5): 204-207.

23. Ojekale $A B$, Lawal $O A$, Segun $A A$, Samuel FO, Ismaila $A l$, Opoku AR. Volatile constituents, antioxidant and insecticidal activities of essential oil from the leaves of Thaumatococcus danielli (Benn.) Benth. from Nigeria. losrphr Org 2013; 3(3): 1-5.

24. Parthipan B, Suky MGT, Mohan VR. GC-MS analysis of phytocomponents in Pleiospermium alatum (Wall. ex Wight and Arn.) Swingle, (Rutaceae), J Pharmacog Phytochem 2015; 4(1): 216-222. 
25. Huang ZR, Lin YK, Fang JY. Biological and pharmacological activities of squalene and related compounds: potential uses in cosmetic dermatology. Molecules 2009; 14: 540-554.

26. Ram M, Rao K. Antioxidant study and GC-MS analysis of an ayurvedic medicine Talisapatradi choornam. Int $J$ Pharm Sci Rev Res 2016; 36(1): 158-166.

27. Okokon JE, Anwanga EU, Samuel GF, Nsikak MU. Antiinflammatory and antipyretic activities of Panicum maximum. Afr J Biomed Res 2001; 14: 125-130.

28. Younis M, Elmegeed GA, Nassar MI. The aqueous ethanol and ethyl acetate extracts of Acacia ehrenbergiana shoots showed moderate antimicrobial activity Egypt J Microbiol 2003; 38(2): 195-205.
29. Kanife UC, Odesanmi OS. Phytochemical composition and antifungal properties of the leaf, stem and florets of Panicum maximum Jacq. (Poaceae). Int J Biol 2012; 4(2): 64-69.

30. Sharma $C$, Aneja $K R$, Surain $P$, Dhiman $R$, Jiloha $P$, Meashi $V$, Kaur $M$. In vitro evaluation of anti-microbial spectrum of Acacia nilotica leaves and bark extracts against pathogens causing otitis infection. J Innov Biol 2014; 1: 51-56.

31. Diao WR, Hu QP, Zhang $H, X u$ JG. Chemical composition, antibacterial activity and mechanism of action of essential oil from seeds of fennel (Foeniculum vulgare Mill.). Food Control 2014; 35: 109-116. 